\title{
Smart Home Controlling and Monitoring System using Multiboard Client-Server Internet of Things (IoT)
}

\author{
T P Zuhelmi ${ }^{1}$, S R Sulistiyanti ${ }^{1 *}$, F X A Setyawan ${ }^{1}$, and A R Adnan ${ }^{1}$ \\ ${ }^{I}$ Department of Electrical Engineering, Faculty of Engineering, Universitas Lampung, Gd. H Lt. 2, Jl. Prof. Soemantri \\ Brodjonegoro No. 1, Bandar Lampung, 35145, Indonesia \\ "Email:sr_sulistiyanti@eng.unila.ac.id
}

\begin{tabular}{|c|c|}
\hline Article Information & Abstract \\
\hline $\begin{array}{l}\text { Received: } \\
16 \text { October } 2019\end{array}$ & $\begin{array}{l}\text { An increasing number of crimes in society make people want to take advantage } \\
\text { of technological developments to improve their safety and comfort. This paper } \\
\text { research the possibilities to make house secure and comfort by using internet }\end{array}$ \\
\hline $\begin{array}{l}\text { Received in revised form: } \\
18 \text { November } 2019\end{array}$ & $\begin{array}{l}\text { of things (IoT) to control and monitor also well known as smart house. This } \\
\text { paper using NodeMCU ESP-12E for the IoT controller and smartphone for } \\
\text { user to control and monitor house environment. The results shows that the }\end{array}$ \\
\hline Accepted: & $\begin{array}{l}\text { system designs for smart home are promising. The sensors response time for } \\
\text { average response time is } 2.52 \text { seconds for solenoid door lock, the average }\end{array}$ \\
\hline 12 December 2019 & $\begin{array}{l}\text { responses time for motion detection testing is } 2.30 \text { seconds, the average } \\
\text { response time for first lamp is } 3.71 \text { seconds and } 4.37 \text { seconds for second lamp, }\end{array}$ \\
\hline $\begin{array}{l}\text { Volume } 1 \text {, Issue 2, December } 2019 \\
\text { pp. } 68-73\end{array}$ & $\begin{array}{l}\text { the average response time is } 1.74 \text { seconds for } L P G \text { gas leakage, the average } \\
\text { response time is } 2.59 \text { seconds for front terrace and } 2.17 \text { seconds for back } \\
\text { terrace. }\end{array}$ \\
\hline
\end{tabular}

CUniversitas Lampung

http://dx.doi.org/10.23960/jesr.v1i2.19

Keywords: smart home, multiboard client-server, IoT.

\section{INTRODUCTION}

$\mathrm{N}$ owadays, criminalities in communities are increasing. However, security and comfort are needed for human being mainly in their house. According to BPS statistics there is 352.936 criminal cases during 2015 and increasing in to 357.197 cases in 2016 [1].

Smart home is become well known word for secure, comfort and energy efficient in house. A lot of research has been conducted using latest technology. This paper research the possibilities to made home secure and comfort by using internet of things (IoT) to control and monitor also well known as smart house. The NodeMCU ESP-12E based Internet of Things (IoT) is used as the smart home controller. The focus of this research is how to develop client server communication for multiboard NodeMCU ESP-12E to extend the monitoring and controlling possibilities.

\section{LITERATURE REVIEW}

The works by [2] develop monitoring system using
BCM 2835. The system using internet-based website for monitoring system and send notification to users by short message service (SMS). The result shows that the monitoring system can be used to monitor the state of internet connection and send notification to networks administrator during failures.

The works by [3] develop smart home system using Raspberry Pi 3 on mobile GSM internet. This research focus on how to control and monitor smart house using mobile devices since the mobile device users are rapidly increased.

The works by [4] develop smart home system using FLIP smart home shield microcontroller. This research develops monitoring and control of household equipment through data transfer and communication using Wi-Fi. The results therefore can be monitored by MQTT websites.

IoT is a concept of communications between things or objects in a small scale. The objects may be a embedded devices or a sensor to sensing and collecting data from environments. Thus, the IoT technologies can be used for smart home implementations. 


\section{METHODS}

This research focuses on home security, comforts, and energy efficiency. The testbed consists of 5 NodeMCU ESP-12E, 1 for server and 4 for clients. The first client is used to monitor and control the home door. The second client is used to monitor and control the state of lamp in the living room. The third client is used to monitor and control the gas, blower is activated when the controller detects the gas level threshold. The fourth client is used to monitor and control the state of lamp in the home terrace. The positions of each controller are depicted in Fig 1.

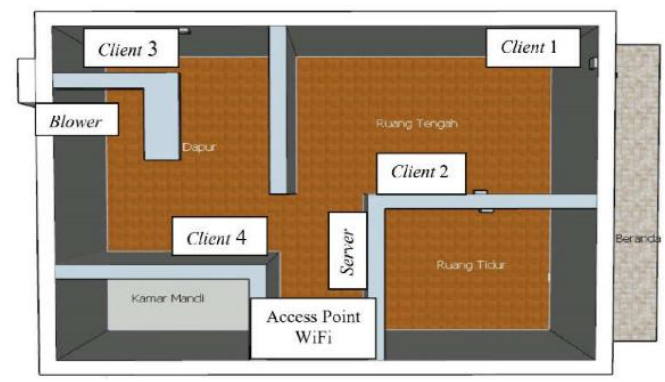

Fig. 1. Controller positions

Therefore, All NodeMCU ESP-12E clients send its collected data to the serer board. NodeMCU ESP-12E that positioned as the server board is should connected to network using Wi-Fi. The application based on android in a smartphone then is used to monitor and control the smart home. The data flow and communication of each devices is depicted in Fig 2.

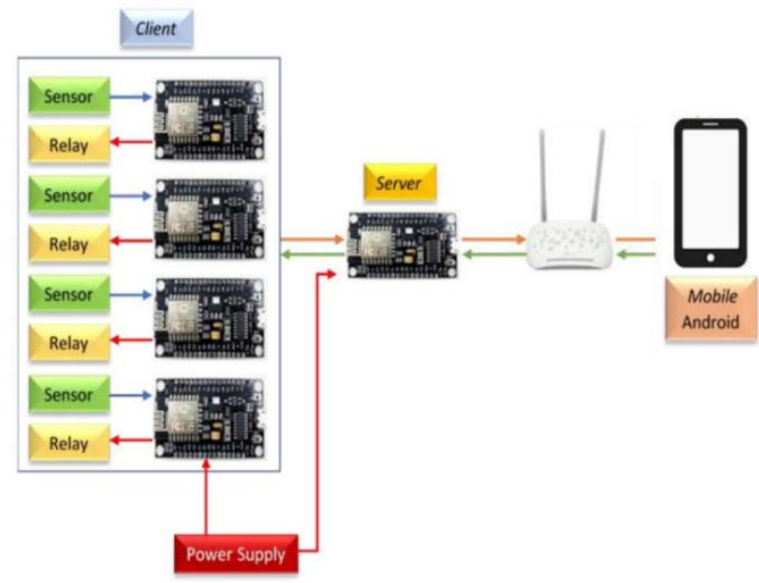

Fig. 2. Data communication models

This tested is used several types of sensors and components as follows:

1. Passive Infra-Red (PIR) HC-SR501 is a motion detection sensor [5].

2. LPG (Liquefied Petroleum Gas) MQ-6 is a sensor to sensing the level of LPG, CH4, and Propane gas [6].

3. Door magnetic sensor MC-38 is used to sensing the door state [7].

4. Solenoid Door Lock to control open and close the door.

5. PCF8574 (I ${ }^{2} \mathrm{C}$ GPIO Expander) is used for microcontroller I/O Expander using $\mathrm{I}^{2} \mathrm{C}$ with SDA and SCL line [8].

6. LCD OLED 0.91 " I2C is a high-resolution display panel [9].

\section{RESUlTS AND DISCUSSION}

\section{A. Mobile based monitor and control system}

The results of this research are a system of smart home consists of several microcontroller boards in client server configuration that connected with sensors and relays. Each client board sends the data status to the server board. Monitoring and controlling the smart home devices are using mobile application that developed under android by connected to the Wi-Fi. Figure 3 and 4 depicted the monitor and control application.

Fig 3 shows the status of terrace, its monitor the status of terrace lamp, door lock, motion, and alarm status. The monitor the lamp status in the living room and back home terrace. The status of gas leakage in the kitchen is also monitored by system and triggered alarm if the gas leakage is above the threshold. The mobile application also provide menu to control the lamp in each room. Figure 4 shows the management menu to change the access password to mobile application. It is also providing door lock control system to control the door lock from remote area.

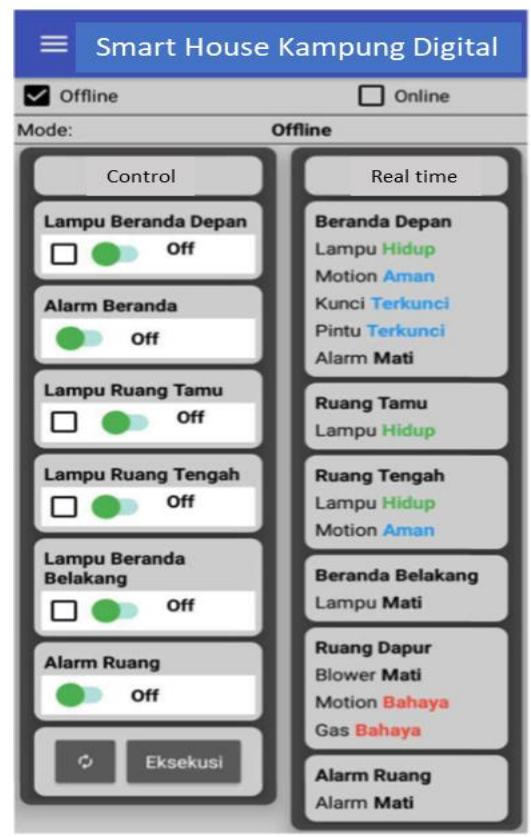

Fig. 3. Mobile app monitor and control system 


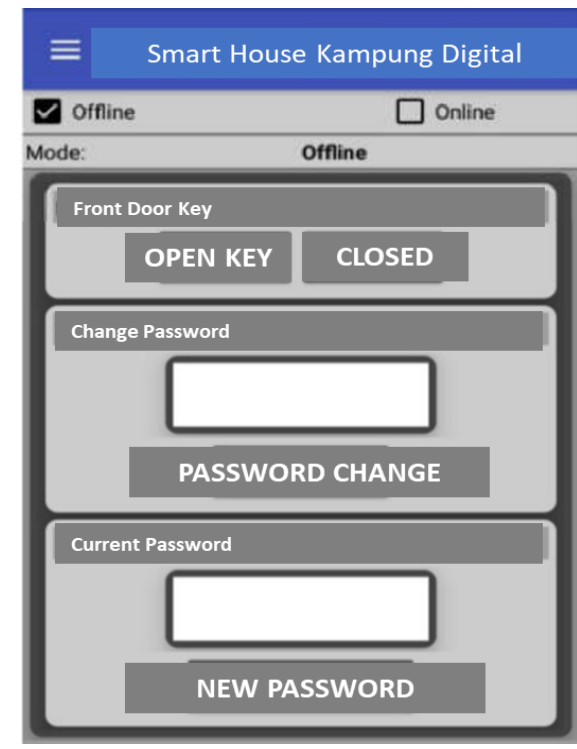

Fig. 4. Management access menu

\section{B. Mobile based monitor and control system}

This testing is done to prove the system is working as expected. The testing is done 10 times and also measures the time response. Time response is amount of time that needed to system to response the command initiated by mobile application.

\section{Client 1 microcontroller board}

1) Solenoid door lock

Client 1 microcontroller board is used to control the solenoid door lock sensor MC-38. The testing is done by give the initial state of the door lock is opened or closed. The, tester then control the door by using mobile application and the time response is noted. Table 1 shows the testing results, it shows that average response time is 2.52 seconds. The door lock final condition after testing also shows the same condition as the expected results conditions. Therefore, the client microcontroller is passed the testing.

Table 1. Solenoid Door (MC-38) Controller Testing

\begin{tabular}{ccccc}
\hline No & $\begin{array}{c}\text { Initial } \\
\text { condition }\end{array}$ & $\begin{array}{c}\text { Expected } \\
\text { condition }\end{array}$ & $\begin{array}{c}\text { Final } \\
\text { condition }\end{array}$ & $\begin{array}{c}\text { Response } \\
\text { time (s) }\end{array}$ \\
\hline 1 & Closed & Opened & Opened & 2.24 \\
2 & Closed & Opened & Opened & 3.55 \\
3 & Closed & Opened & Opened & 2.88 \\
4 & Closed & Opened & Opened & 2.65 \\
5 & Closed & Opened & Opened & 1.65 \\
6 & Opened & Closed & Closed & 1.78 \\
7 & Opened & Closed & Closed & 2.91 \\
8 & Opened & Closed & Closed & 3.28 \\
9 & Opened & Closed & Closed & 2.69 \\
10 & Opened & Closed & Closed & 1.58 \\
\hline
\end{tabular}

\section{2) Motion detection sensors}

Motion detection sensors are using HC-SR501. Testing is done with initial condition without motion object, then introduce the motion/moving object in motion sensing area. Feedback from motion sensors until user get the notification in mobile applications is noted as the responses time. Table 2 shows the average responses time for motion detection testing is 2.30 seconds.

Table 2. Motion Detection Hc-Sr501 Response Time

\begin{tabular}{cc}
\hline Number of tests & Response time (s) \\
\hline 1 & 3.80 \\
2 & 1.85 \\
3 & 3.02 \\
4 & 3.09 \\
5 & 2.64 \\
6 & 1.85 \\
7 & 1.29 \\
8 & 1.78 \\
9 & 2.03 \\
10 & 1.65
\end{tabular}

\section{Client 2 microcontroller board}

1) Lamp controller

Client 2 is used to monitor and control lamp status in living room. There are 2 main lamps that located inside the home living room. The testing is done 10 times with several condition, expected results and final results and response time is noted. The response time is amount of time that needed to system to response the command initiated by mobile application. Table 3 and Table 4 show the average response time for first lamp is 3.71 seconds and 4.37 seconds for second lamp. The living room lamp final condition after testing also shows the same condition as the expected results conditions.

Table 3. First Living Room Lamp Controller Testing

\begin{tabular}{ccccc}
\hline No & $\begin{array}{c}\text { Initial } \\
\text { conditions }\end{array}$ & $\begin{array}{c}\text { Expected } \\
\text { conditions }\end{array}$ & $\begin{array}{c}\text { Final } \\
\text { results }\end{array}$ & $\begin{array}{c}\text { Time } \\
\text { response (s) }\end{array}$ \\
\hline 1 & Closed & Opened & Opened & 3.44 \\
2 & Closed & Opened & Opened & 2.62 \\
3 & Closed & Opened & Opened & 2.87 \\
4 & Closed & Opened & Opened & 4.61 \\
5 & Closed & Opened & Opened & 3.10 \\
6 & Opened & Closed & Closed & 4.83 \\
7 & Opened & Closed & Closed & 3.26 \\
8 & Opened & Closed & Closed & 4.71 \\
9 & Opened & Closed & Closed & 4.99 \\
10 & Opened & Closed & Closed & 2.76 \\
\hline
\end{tabular}


Table 4. Second Living Room Lamp Controller Testing

\begin{tabular}{ccccc}
\hline No & $\begin{array}{c}\text { Initial } \\
\text { conditions }\end{array}$ & $\begin{array}{c}\text { Expected } \\
\text { conditions }\end{array}$ & $\begin{array}{c}\text { Final } \\
\text { results }\end{array}$ & $\begin{array}{c}\text { Time } \\
\text { response (s) }\end{array}$ \\
\hline 1 & Closed & Opened & Opened & 4.04 \\
2 & Closed & Opened & Opened & 5.77 \\
3 & Closed & Opened & Opened & 2.84 \\
4 & Closed & Opened & Opened & 4.54 \\
5 & Closed & Opened & Opened & 3.61 \\
6 & Opened & Closed & Closed & 5.25 \\
7 & Opened & Closed & Closed & 5.99 \\
8 & Opened & Closed & Closed & 4.76 \\
9 & Opened & Closed & Closed & 2.47 \\
10 & Opened & Closed & Closed & 4.46 \\
\hline
\end{tabular}

2) Client 3 microcontroller board (LPG gas leakage and blower controller)

Client 3 is used to monitor the LPG gas leakage located in the kitchen. System will notify the user through the mobile application. The system will also control the blower if the gas leakage is above the threshold. The testing is done by give the sensors the LPG gas, the response time when the sensors detect the gas and time needed to notify user on mobile applications is noted. Table 5 shows the average response time is 1.74 seconds.

3) Client 4 microcontroller board (lamp controller)

Client 4 is used to monitor and control lamp status in living room. There is 2 main lamp that located in the front and back home terrace. The testing is done 10 times with several condition, expected results and final results and response time is noted. The response time is amount of time that needed to system to response the command initiated by mobile application. The average response time is 2.59 seconds for front terrace and 2.17 seconds for back terrace.

Table 5. Second Living Room Lamp Controller Testing

\begin{tabular}{ccc}
\hline No & Number of test- & Response time (s) \\
\hline 1 & 1 & 1.38 \\
2 & 2 & 1.25 \\
3 & 3 & 1.26 \\
4 & 4 & 1.38 \\
5 & 5 & 1.06 \\
6 & 6 & 2.89 \\
7 & 7 & 1.58 \\
8 & 8 & 1.19 \\
9 & 9 & 2.50 \\
10 & 10 & 2.88 \\
\hline
\end{tabular}

Table 6. Front Terrace Lamp Testing

\begin{tabular}{ccccc}
\hline No & $\begin{array}{l}\text { Initial } \\
\text { conditions }\end{array}$ & $\begin{array}{l}\text { Expected } \\
\text { conditions }\end{array}$ & $\begin{array}{l}\text { Final } \\
\text { results }\end{array}$ & $\begin{array}{l}\text { Time } \\
\text { response (s) }\end{array}$ \\
\hline 1 & Closed & Opened & Opened & 2.62 \\
2 & Closed & Opened & Opened & 2.06 \\
3 & Closed & Opened & Opened & 2.66 \\
4 & Closed & Opened & Opened & 2.10 \\
5 & Closed & Opened & Opened & 2.45 \\
6 & Opened & Closed & Closed & 2.47 \\
7 & Opened & Closed & Closed & 2.02 \\
8 & Opened & Closed & Closed & 2.02 \\
9 & Opened & Closed & Closed & 3.68 \\
10 & Opened & Closed & Closed & 3.88 \\
\hline
\end{tabular}

Table 7. Back Terrace Lamp Controller Testing

\begin{tabular}{ccccc}
\hline No & $\begin{array}{l}\text { Initial } \\
\text { conditions }\end{array}$ & $\begin{array}{l}\text { Expected } \\
\text { conditions }\end{array}$ & $\begin{array}{l}\text { Final } \\
\text { results }\end{array}$ & $\begin{array}{l}\text { Time } \\
\text { response (s) }\end{array}$ \\
\hline 1 & Closed & Opened & Opened & 2.60 \\
2 & Closed & Opened & Opened & 2.67 \\
3 & Closed & Opened & Opened & 3.80 \\
4 & Closed & Opened & Opened & 2.36 \\
5 & Closed & Opened & Opened & 2.46 \\
6 & Opened & Closed & Closed & 2.29 \\
7 & Opened & Closed & Closed & 2.08 \\
8 & Opened & Closed & Closed & 3.18 \\
9 & Opened & Closed & Closed & 3.67 \\
10 & Opened & Closed & Closed & 2.00 \\
\hline
\end{tabular}

\section{CONClusions}

From this research results we may conclude that smart home concept using IoT devices in multiboard client-server model is well implemented. The longest response time is generated at the second lamp controller on client 2 of the microcontroller board and the shortest time response is generated by the blower controller and LPG gas leakage on client 3 of the microcontroller board. Further works can be carried out using other micro-controllers that have better microprocessors to reduce response time.

\section{ACKNOWLEDGEMENT}

Thanks for the Directorate of Research and Community Service who provided funding through The Master Thesis Research (PTM) 2019 scheme. 


\section{REFERENCES}

[1] BPS RI, "Statistik Indonesia 2018," Badan Pusat Statistik. p. 719, 2018.

[2] D. Despa, A. Kurniawan, M. Komarudin, Mardiana, and G. F. Nama. (2015). Smart Monitoring of Electrical Quantities Based on Single Board Computer BCM2835. Proceeding of the $2^{\text {nd }}$ International Conference on Information Technologies, Computer, and Electrical Engineering (ICITACEE 2015), IEEE Explorer, pp. 315-320.

[3] M. B. Nurfaif, S. R. Sulistiyanti, M. Komarudin and G. F. Nama. (2017). Telemetry and tele-control of electronic appliances for smart-home-system. Proceeding of International Symposium on Electronics and Smart Devices (ISESD 2017), IEEE Explorer, pp. $18-23$.
[4] T. Malche and P. Maheshwary. (2017). Internet of Things (IoT) for building smart home system. Proceeding of 2017 International Conference on IoT in Social, Mobile, Analytics and Cloud, I-SMAC Palladam-2017, IEEE Explorer, pp. 65-70.

[5] Allelectronics, HC-SR501 PIR Motion Detector. Available: https://www.allelectronics.com, 2018.

[6] Hanwei Sensors, 2018. Technical Data MQ-6 Gas Sensor. [Online]. Accessed: www.hwsensor.com, 26 April 2018.

[7] VSTAR, Magnetic contact. Available [Online]. Accessed: https://www.hkvstar.com, 26 April 2018.

[8] 128 x 32 Graphic OLED, Available [Online]. Accessed: www.vishay.com, 26 April 2018.

[9] M, A. Heryanto, dan W. Adi P, "Pemrogaman Bahasa C untuk Mikrokontroller ATMega8535”. Yogyakarta, Indonesia: Penerbit Andi, 2007, $1^{\text {st }}$ edition, p. 226. 